\title{
Pengembangan Bahan Ajar Berbasis E-Learning pada Pembelajaran Tematik Sekolah Dasar
}

\author{
Heni Wijayanti ${ }^{1}$, I Nyoman Sudana Degeng ${ }^{2}$, Nurmida Catharine Sitompul ${ }^{3}$ \\ ${ }^{1,3}$ Teknologi Pendidikan, Pascasarjana, Universitas PGRI Adi Buana Surabaya \\ ${ }^{2}$ Teknologi Pembelajaran, Pascasarjana Universitas Negeri Malang
}

\section{Edcomtech}

\section{Jurnal Kajian}

Teknologi Pendidikan

Volume 6, No 1, April 2021

26-35

Submitted 04-05-2020

Accepted 02-06-2020

Corresponding Author

Heni Wijayanti

heni@sdalfalahassalam.sch.id

\begin{abstract}
Abstrak
Teknologi dalam bidang Pendidikan telah berkembang pesat, salah satunya adalah munculnya E-learning. Penelitian ini bertujuan untuk mengembangkan bahan ajar tematik pendamping guru berbasis E-learning. Pengembangan bahan ajar menggunakan model pengembangan Borg and Gall terdiri atas 10 langkah. Data dikumpulkan melihat kelayakan produk E-learning. Data angket dari ahli isi/materi, ahli media, ahli desain, teman sejawat dan 24 siswa. Teknik analisis data bersifat deskriptif. Hasil reviu kelayakan produk pengembangan:1) review ahli isi/materi 97\%,2) reviu ahli media 83\%, 3) reviu ahli desain 88\%, 4) uji coba perorangan 90\%, 4) uji coba kelompok 93\%, 5) uji coba produk terhadap siswa persentase $83 \%$. Nilai rata-rata keseluruhan uji kelayakan adalah $89 \%$. Dengan kriteria kelayakan sangat baik.
\end{abstract}

Kata Kunci: pengembangan bahan ajar, tematik, e-learning, model Borg and Gall, pendidikan dasar

\begin{abstract}
Technology in education, one of which is e-learning, requires the appropriate teaching materials in the implementation of thematic. By using the descriptive qualitative method, the results showed as follows: 1) content expert review is 97\%. 2) media expert review is 83\%, 3) design expert review 88\%, 4) individual product trial is $90 \%, 5)$ product group trial is $93 \%$,6) product trials on students and student responses through questionnaires is $83 \%$. The average score of the overall feasibility test is $89 \%$. With the 'very good' feasibility criteria, the product developed is appropriate to be used as supplementary teaching materials in thematic learning.
\end{abstract}

Keywords: materials development, thematic, e-learning, Borg and Gall model, primary education 


\section{LATAR BELAKANG}

Implementasi Kurikulum 2013 di Sekolah Dasar diterapkan dengan menggunakan pendekatan tematik. Penerapan kurikulum ini membutuhkan penyediaan bahan ajar untuk guru, yang saat ini belum dapat disediakan pemerintah secara optimal. Penelitian ini bertujuan untuk mengembangkan produk bahan ajar tematik pendamping siswa dengan model $e$-learning.

Peneliti tertarik untuk mengembangkan bahan ajar berbasis e-learning yang dilakukan melalui penelitian yang berjudul "Pengembangan Bahan Ajar Tematik Berbasis E-Learning Dalam Pembelajaran Tematik SD di Sekolah Dasar". Hal ini didasarkan alasan bahwa; 1) bahan ajar merupakan suatu persoalan yang penting dan menarik untuk dikembangkan, karena bahan ajar merupakan alat bantu dalam proses pembelajaran, 2) siswa lebih termotivasi pembelajarannya dengan adanya bahan ajar yang interaktif dan mengaplikasi teknologi, 3) bahan ajar tematik yang ada sekarang belum relevan terhadap karakteristik peserta didik sehingga peneliti tertarik untuk menyumbangkan produk pengembangan bahan ajar yang dapat meningkatkan kemenarikan dan keefektifan pembelajaran

Arsah (2019) menyatakan bahwa " the

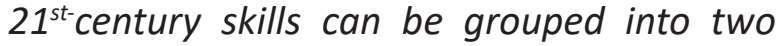
main components abstract skills related to thinking skills (creative thinking and critical thinking), and concrete skills (communication and collaboration)". Keterampilan abad ke 21 dapat diklasifikasikan dalam dua aspek utama, adalah keterampilan nyata dan keterampilan tidak nyata yang berkaitan erat dengan berpikir kreatif dan kritis. Keterampilan abad 21 menuntut guru untuk kreatif dalam menciptakan media dan bahan mengajar yang relevan. Kurikulum 2013 berkembang berdasarkan hakikat perubahan globalisasi dan kemajuan teknologi (Suyantiningsih, Munawaroh, \& Rahmadona, 2016). Senada pendapat Agustina, Al Muhdhar, \& Amin (2017) bahwa tuntutan pembelajaran berbasis pada kompetensi dan karakter bangsa supaya siswa dapat menyelaraskan diri dengan kehidupan. Orang-orang yang sukses pada abad ke-21 adalah mereka yang memiliki kreatifitas dan inovatif serta memiliki ide yang cemerlang. Dalam hal ini siapa lagi yang akan berperan menciptakan berbagai keterampilan kreatif dan inovatif itu jika bukan guru. Guru tidak hanya menunggu dan berharap terhadap kemampuan dasar siswa berkembang secara sendirinya pada tahap kemampuan operasional menjelaskan, melainkan harus mampu menciptakan siswa yang mampu pada level kemampuan berpikir mendeskripsikan sesuatu, atau bahkan menciptakan sesuatu. Selain ini juga mampu menyampaikan gagasan-gagasan baru kepada yang lain, bersikap terbuka dan responsif terhadap pengetahuan baru (Mardliyah, 2019).

Pendekatan tematik terpadu dalam pembelajaran sangat dipengaruhi oleh gagasan tentang interdisciplinary pelaksanaan kurikulum. Gagasan ini terwujud sebagai tanggapan terhadap adanya ilmu pengetahuan yang bersifat menyeluruh, sebagai akibat dari peningkatan keragaman ilmu pada sebuah penelitian. Munculnya gagasan interdisciplinary curriculum juga dipicu oleh praktik pembelajaran di sekolah, di mana setiap hari seorang siswa harus menyiapkan beberapa pelajaran. Pelajaran dilakukan oleh seluruh bidang studi dan siswa melakukan persiapan terhadap beberapa bidang studi tersebut. Tentu saja guru pun harus melakukan persiapan yang sama. Sehingga pembelajaran terputus-putus dan sangat kurang hubungannya antara satu materi ke materi yang lain meskipun pada hari yang sama. Munculnya gagasan kurikulum melalui program pengajaran dengan interaksi intensif di dunia pengajaran tersebut sebagai suatu bentuk temuan di masyarakat bahwa perkembangan seorang individu tidak hanya berlangsung dalam satu program ilmu saja, melainkan melalui berbagai program pengajaran dan penelitian dengan tujuan melakukan integrasi konsep, metode, dan analisis (Wahyuni, 2018).

Dalam mewujudkan pembelajaran yang efektif dan dinamis maka diperlukan sumber belajar yang dapat membantu pelaksanaan proses pembelajaran. Sumber belajar dapat dikatakan sebagai landasan belajar dalam memperoleh pengetahuan 
(Thaariq, 2020). Salah satu contohnya adalah bahan ajar (Surahman et al., 2020). Dewasa ini ada berbagai macam terbitan dan karya modul belajar dengan bermacam inovasi. Diantaranya adalah bahan ajar dengan berbasis pada teknologi atau lebih dikenal dengan nama bahan ajar e-learning.

Prastowo (2011) menyatakan bahwa bahan ajar merupakan kumpulan beberapa materi yang disusun secara terperinci baik secara tertulis maupun non tulis, sehingga bisa dimanfaatkan oleh siswa sebagai alat untuk belajar. Pendapat lain menyatakan bahwa bahan ajar merupakan suatu teks, alat dan informasi yang dipergunakan oleh guru untuk mentransformasi ilmu dan pengetahuannya, baik sebagai alat maupun bahan informasi untuk pelaksanaan pembelajaran. Berdasarkan pada definisi tersebut, Pannen (Prastowo, 2011) menjelaskan bahan ajar sebagai materi yang tersusun secara terstruktur yang dapat digunakan oleh siswa dan guru untuk mencapai tujuan dalam proses belajar.

Kualitas pembelajaran yang baik seharusnya didukung oleh literatur yang baik pula (Mursanti, Fatirul, \& Hartono, 2020). Adanya bahan ajar mempermudah siswa dalam menerima materi yang diberikan (Pratiwi, Hidayah, \& Martiana, 2017). Sumber belajar berupa bahan ajar merupakan salah satu unsur penting dalam terbentuknya sebuah pembelajaran. Keberadaan bahan ajar akan membantu guru mendesain pembelajaran, sedangkan bagi peserta didik, bahan ajar akan membantu mereka dalam menguasai kompetensi pembelajaran. Pemerintah telah berupaya memenuhi kebutuhan bahan ajar kurikulum 2013 dengan menyediakan buku guru dan buku siswa. Ketersediaan buku guru bertujuan sebagai pedoman minimal bagi guru dalam melaksanakan proses pembelajaran berdasarkan kurikulum 2013, sedangkan buku siswa merupakan buku yang disediakan untuk membantu peserta didik dalam proses belajar dan menguasai kompetensi yang diharapkan (Kimianti \& Prasetyo, 2019).

E-learning tergolong media dalam pembelajaran yang bersifat elektronik dan bisa dilakukan dengan interaktif untuk meningkatkan minat belajar anak-anak.
Arham \& Dwiningsih (2016) bahwa dengan menggunakan bermacam media interaktif dan menarik bagi siswa dapat meningkatkan motivasi dan hasil belajar siswa meningkat, sehingga pada akhirnya tujuan dalam pembelajaran bisa tercapai dengan baik, secara teori maupun praktik. Begitu pula penelitian yang dilakukan oleh Amidi \& Zahid (2017), Safitri (2018) dan RW, Mayasari, \& Huriawati (2017) yang berpendapat yaitu dengan melalui media e-learning cara berpikir kreatif siswa dapat tumbuh dengan baik.

Zareetal (2016) yang membuktikan bahwa e-learning sangat efektif untuk meningkatkan pemahaman mengenai pengetahuan dan segi keterampilan. Alasan penting menggunakan e-learning yaitu untuk memberikan alternatif pembelajaran interaktif pada era milenial dengan memanfaatkan teknologi yang ada. Melalui media e-learning kegiatan belajar siswa dimungkinkan sangat efektif dan bisa berlangsung secara fleksibel. Karena siswa dapat mengakses pembelajaran tanpa terpengaruh oleh waktu dan tempat baik itu bahan - bahan pembelajaran maupun latihan soal, bahkan bisa dilakukan secara berulang. khususnya untuk pengembangan materi dalam pembelajaran dan peserta didik langsung dapat menerapkan hasil belajarnya dalam kehidupan nyata. Selain itu peserta didik dan pengajar dapat berkomunikasi setiap saat, misalnya melalui chatting dan email, sehingga tujuan pembelajaran secara optimal dapat tercapai (Susilo \& Suhardi, 2018).

Potensi pengembangan e-learning berbentuk sebagai bagian dari pengembangan media pembelajaran yang harus dilakukan oleh pendidik. Penggunaan media dalam pembelajaran dapat membantu keterbatasan pendidik dalam menyampaikan informasi maupun keterbatasan jam pelajaran di kelas. Hal ini sesuai dengan pernyataan bahwa media pembelajaran dapat digunakan sebagai sumber informasi materi pembelajaran maupun sumber soal latihan sehingga dapat membantu keterbatasan pembelajaran yang tidak dapat dilakukan oleh pendidik saja (Yektyastuti \& Ikhsan, 2016).

Sesuai pendapat Suryosubroto (2009) pembelajaran tematik adalah kegiatan belajar 
yang menyatukan domain pengetahuan, sikap, danketerampilandenganmenggunakansatuan tema. Sedangkan Trianto (2010) berpendapat pembelajaran dengan pendekatan tematik merupakan kegiatan pembelajaran yang mengintegrasikan berbagai mata pelajaran dengan menggunakan tema tertentu. Implementasi kurikulum 2013 mengajak siswa dan guru belajar tidak menggunakan mata pelajaran lagi melainkan dengan menggunakan tema, baik pada jenjang pendidikan dasar, pendidikan menengah maupun pendidikan atas (Anshory, Saputra, \& Amelia, 2018).

Pendekatan tematik terpadu adalah kegiatan pembelajaran yang menggunakan tema sebagai alat untuk mengintegrasikan mata pelajaran (Tim Penyusun, 2013). Kegiatan dalam pembelajaran tematik cenderung integratif, dimana peserta didik tidak belajar sesuai mata pelajaran yang terpisah-pisah, semua mata pelajaran yang ada di sekolah dasar sudah terintegrasi menjadi satu kegiatan pembelajaran yang diikat dengan tema.

Cara yang diterapkan dalam pelaksanaan kurikulum 2013 adalah metode tematik integratif yang menggabungkan bidang studi dalam kesatuan yang disebut dengan tema. Dalam konsepnya siswa tidak belajar secara luas tentang materi dasar, namun konsep materi disajikan dalam kegiatan yang bermakna. Beberapa contoh tema - tema yang diambil adalah tema sesuai dengan kehidupan sehari-hari, kehidupan alam, dan segala yang berkaitan erat dengan manusia dan sekitarnya. Contoh penggabungan mata pelajaran bermakna integratif adalah mata pelajaran Bahasa Indonesia, Matematika, PPKn, IPS, IPA, Seni Budaya dan Olahraga (Tay \& Destya, 2017).

Sekolah diyakini merupakan tempat dimana nilai - nilai terhadap perkembangan teknologi dibangun. Namun pelaksanaan pembelajaran di kelas masih terkesan kontekstual dan hanya mengacu pada satu bahan ajar saja. Dengan tersedianya bahan ajar tematik berbasis e-learning yang dirancang dengan memperhatikan karakteristik siswa diharapkan dapat mengakomodasi pembelajaran di kelas,untuk memberikan motivasi pada siswa dan guru untuk melaksanakan kegiatan belajar relevan, interaktif dengan mengaplikasi teknologi. Pada riset sebelumnya yang dilakukan oleh (Wahyuni, 2018) menyatakan bahwa pengembangan bahan ajar yang berupa produk elektronik atau produk cetak sangat berpengaruh terhadap proses pembelajaran. Dalam penelitian yang berjudul "Pengembangan Bahan Ajar Tematik Pendamping Guru Dengan Model Webbed Untuk Sekolah Dasar Kelas 2" tersebut dihasilkan bahan ajar tematik berbasis webbed untuk membantu pembelajaran, telah diujikan terhadap 24 siswa SD Hasyim Asy'ari Surabaya yang menggunakan teknik analisis data deskriptif dan hasil uji kelayakan mencapai kriteria sangat baik. Pembelajaran dengan menggunakan bahan ajar dan media yang baik akan mengembangkan daya nalar siswa untuk melatih daya kritis, oleh karena itu diperlukan sebuah inovasi dalam pengembangan bahan ajar yang digunakan untuk pembelajaran siswa di kelas Pengembangan bahan ajar ini dengan berbasis e-learning dimaksudkan agar siswa bisa melaksanakan pembelajaran tanpa bertatap muka baik mempelajari materi maupun melaksanakan evaluasi pembelajaran. Konten pembelajaran baik konsep dan pengembangan serta evaluasi bisa diakses melalui handphone maupun komputer.

\section{METODE}

Metode yang digunakan dalam pengembangan penelitian ini lebih mengarah pada model penelitian dan pengembangan yang dilakukan oleh Borg And Gall. Penelitian dan pengembangan pendidikan adalah sebuah prosesyang digunakan untukmengembangkan dan memvalidasi produk pendidikan. Langkah-langkah dalam proses ini biasanya disebut dengan siklus $R \& D$, yang terdiri dari mempelajari temuan penelitian terkait produk yang dikembangkan, mengembangkan produk sesuai dengan temuan, uji lapangan yang telah disesuaikan, dan memperbaiki kekurangan yang ditemukan dalam uji lapangan. Sehingga, mampu menunjukkan bahwa produk tersebut telah sesuai dengan tujuan yang diinginkan (Gall, Gall, \& Borg, 
2003). Selain itu, menurut Degeng (2013: 6) dalam Wahyuni (2018) menjelaskan bahwa bahan ajar sebaiknya dirancang dengan model pengembangan tertentu, dengan memasukan konten pembelajaran dari berbagai sumber karena dengan perancangan yang baik akan menghasilkan produk bahan ajar yang baik.

\section{Prosedur Pengembangan}

Langkah pengembangan bahan ajar yang dimaksud adalah sebagai berikut: observasi dan pengumpulan informasi (observation and information collecting) tahap ini dilakukan dengan mengamati kelas dan melakukan persiapan awal. Merencanakan pengembangan (planning) terdiri dari penentuan kerangka materi bahan ajar diujikan pada kelompok kecil untuk mengukur karakteristik siswa. Mengembangkan konsep awal (develop the initial konsep) kegiatan yang dilakukan pada tahap ini adalah penyiapan materi pembelajaran, alat - alat evaluasi dan kegiatan keterampilan paktik. Kemudian melaksanakan uji awal (preliminary field testing) dalam tahap ini uji produk awal pada sejumlah orang yang disebut kelompok kecil yang terdiri dari 5-10. Selanjutnya revisi product awal (main product revision) dilakukan berfokus pada hasil uji coba pada tahap 4, untuk mendapatkan data kualitatif. Lalu uji coba lapangan (main field testing) hasil produk yang telah dibenahi selanjutnya dicobakan pada subjek yang lebih banyak. melibatkan 24 siswa dan hasilnya sebagai dasar perbaikan produk. Revisi produk lanjutan (operational product revision) kegiatan perbaikan berfokus pada hasil uji coba lapangan. Merupakan tolak ukur keberhasilan karya produk bahan ajar untuk meningkatkan perbaikan pada langkah selanjutnya. Langkah berikutnya adalah uji lapangan (operational field testing) dalam langkah ini pengembang melakukan uji coba produk pada subjek 20-100. Kemudian penyempurnaan produk (final product revision) tahap revisi penyempurnaan setelah uji subjek yang sangat besar. Terakhir adalah kelayakan dan implementasi (dissemination and implementation). Tahap dimana pengembang menyampaikan hasil produknya kepada pengguna dalam forum pembelajaran, untuk diaplikasikan.
Diagram prosedur pengembangan bahan ajar adalah sebagai berikut :

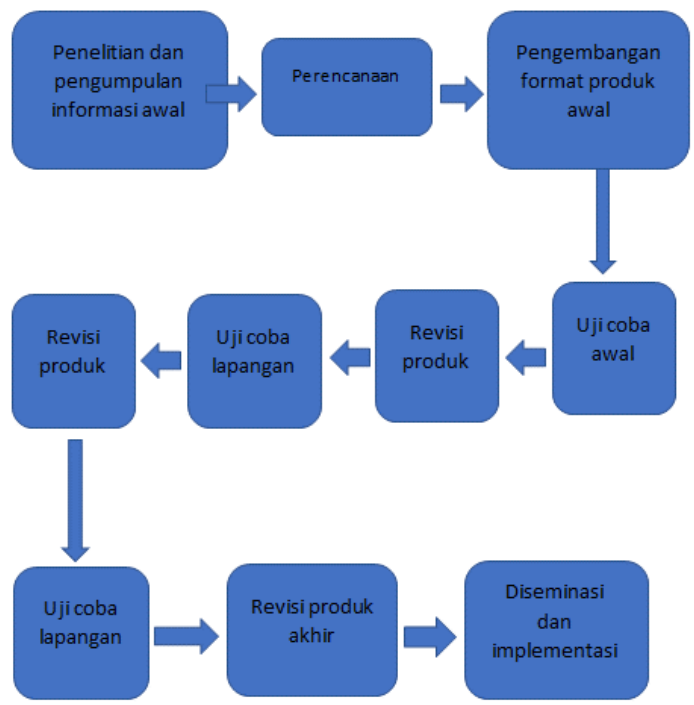

Gambar 1. Diagram Alur Pengembangan Bahan Ajar Borg And Gall

\section{Analisis Data}

Hasil analisis pada data yang sudah diambil selanjutnya akan dianalisis menggunakan rumus data kualitatif sesuai dengan hasil validasi produk ini. Teknik perhitungan kualitatif menggunakan nilai rata-rata. Perhitungan ini bermanfaat untuk mengetahui nilai akhir tiap butir validasi sesuai aspek yang diukur. Menurut Arikunto (2014), rumus perhitungan nilai rata-rata sebagai berikut:

$$
P=\frac{\sum x}{\sum x_{i}} x 100
$$

Keterangan Rumus :

$P \quad=$ presentase

$\Sigma \mathrm{x}=$ total jawaban penilaian

$\Sigma x_{i}=$ total jawaban tertinggi

100 = bilangan konstan

Angket yang diberikan kepada siswa mengandung penilaian dari aspek kelayakan penggunaan bahan ajar tematik berbasis e-learning. Untuk menentukan kelayakan produk maka kuesioner menggunakan skala Likert dengan nilai sebagai berikut: sangat baik = 4 , baik $=3$, kurang $=2$, sangat kurang $=1$. 
Kriteria kelayakan media pembelajaran untuk siswa seperti terlihat dalam tabel berikut ini:

Tabel Kriteria Kelayakan Bahan Ajar Tematik Berbasis E-learning

\begin{aligned} & \hline \multicolumn{1}{r}{ Presentase } Kriteria Kelayakan \\ & \hline $75 \%<\mathrm{P}<100 \%$ Baik \\ & \hline $50 \%<\mathrm{P}<100 \%$ Cukup Baik \\ & \hline $25 \%<\mathrm{P}<100 \%$ Kurang Baik \\ & \hline $0 \%<\mathrm{P}<100 \%$ Tidak Baik \\ & \hline\end{aligned}

\section{HASIL DAN PEMBAHASAN}

Pada bagian ini akan disajikan beberapa gambar bagian dari produk pengembangan atau bahan ajar dari penelitian ini, beberapa contoh produk yang telah dikembangkan antara lain : halaman depan, petunjuk penggunaan, jaringan Kompetensi Dasar, menu utama, isi/materi.

Halaman depan bahan ajar tematik berbasis e-learning berisi tentang portal tampilan username dan password, identitas kelas, dan bidang studi. Produk bahan ajar tematik berbasis e-learning dikemas secara online dengan alamat web http://portal. sdalfalahassalam.sch.id/elearning seperti tampak pada gambar berikut ini:

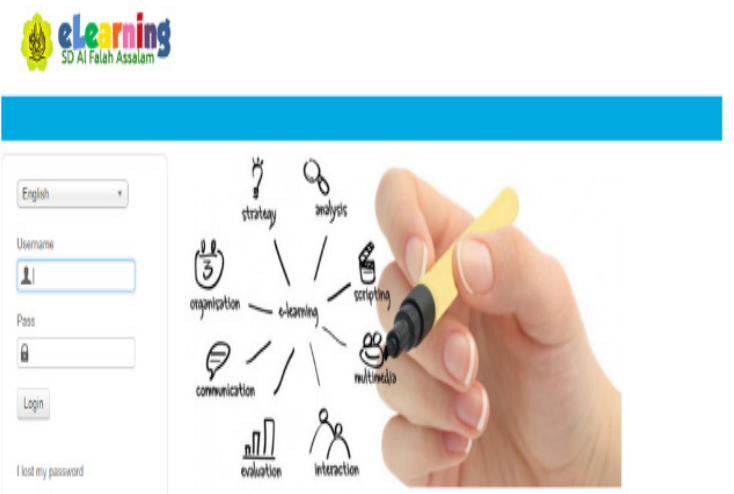

\section{Gambar 2. Tampilan Halaman Depan Program E-learning}

Prosedur penggunaan yang tercantum dalam darf merupakan media yang bertujuan untuk membantu peserta didik dalam mengaplikasikan media e-learning. Dalam bahan ajar berbasis e-learning ini terdapat beberapa tombol aplikasi yang sangat membantu dalam penggunaan e-learning.

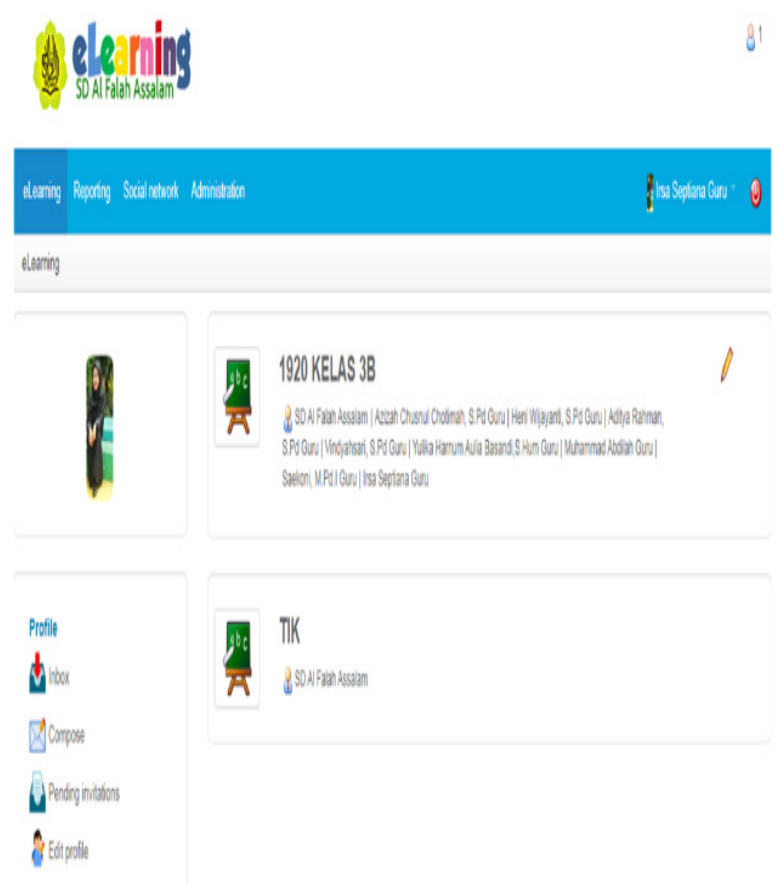

Gambar 3. Tampilan Petunjuk Penggunaan.

Materi dan jaringan kompetensi dasar halaman ini berisi informasi mengenai kompetensi dasar pengetahuan dan keterampilan yang akan dipelajari. Selanjutnya dilengkapi dengan halaman yang berisikan tujuan dari pembelajaran yang akan dilakukan.

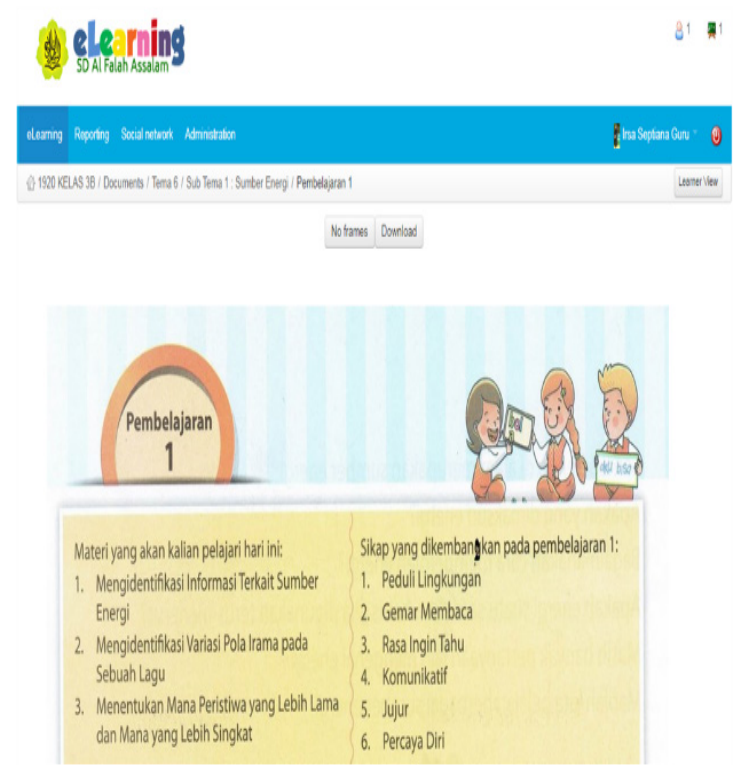

Gambar 4. Contoh Materi Pembelajaran 
Isi Materi bahan ajar tematik berbasis e-learning terdiri atas materi yang meliputi 4 mata pelajaran yaitu Bahasa Indonesia, Matematika, SBDP, PPKN, PJOK, terdiri dari 4 subtema ( subtema 1 , subtema 2 , subtema 3 , subtema 4), masing-masing subtema terdiri dari 6 pembelajaran.

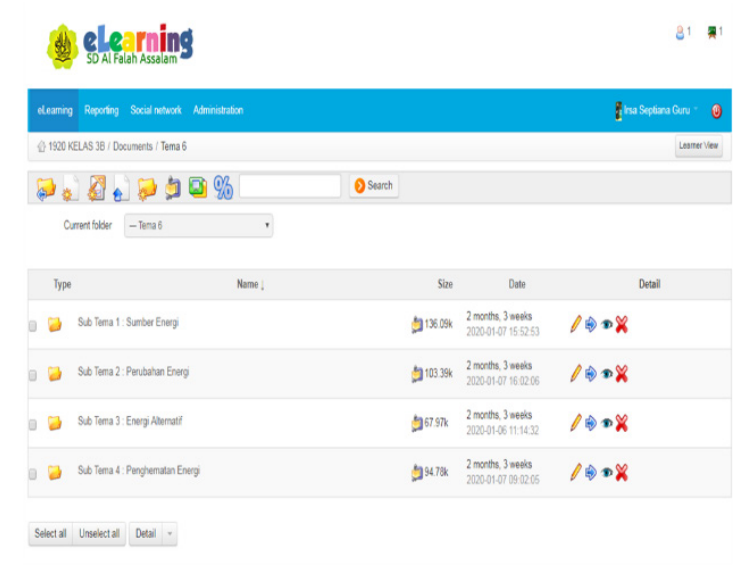

\section{Gambar 5. Substansi Materi Pembelajaran}

\section{Hasil Reviu Ahli}

Reviuahlimateriterdiriatasahlipendidikan Bahasa Indonesia dan pembelajaran tematik adalah dosen pada Fakultas Keguruan dan Ilmu Pendidikan, Kepala UPT PPL dan Ketua PPG Universitas Adi Buana Surabaya. Bapak Dr. Agung Pramono, M.Pd dosen pada program studi Pendidikan Bahasa dan Sastra Indonesia. Hasil penilaiannya sebesar 97\% atau kategori baik. Artinya bahan ajar layak untuk digunakan dengan sedikit revisi

\section{Hasil Reviu Uji Ahli Media Pembelajaran}

Setelah produk direvisi sesuai dengan saran ahli isi, maka selanjutnya dilakukan reviu oleh ahli media yaitu Andri Kurniawan, S.Pd, M.Pd Kepala Laboratorium Produksi Media Pascasarjana UNIPA Dosen pada PG PAUD, Universitas PGRI Adi Buana Surabaya. Hasil penilaiannya sebesar $83 \%$ atau kategori baik.

\section{Hasil Uji Ahli Desain Pembelajaran}

Uji kelayakan ahli desain pembelajaran oleh Dr. H. Ibut Priono Leksono, M. Pd beliau adalah dosen pada program studi Magister (S2) Teknologi Pendidikan, Universitas PGRI Adi Buana Surabaya. Hasil penilaian sebesar 88\% dengan kategori baik, sehingga bahan ajar layak untuk digunakan.

\section{Hasil Uji Coba Perorangan dan Kelompok}

Uji coba perorangan adalah teman sejawat dilakukan di SD Al Falah Assalam dengan responden 2 orang guru tematik dengan latar belakang pendidikan magister. Kedua orang responden mengisi angket yang diberikan oleh pengembang. Fokus utama ingin diperoleh dari pengembang adalah data kesesuain isi/materi dan kesesuaian desain pembelajaran produk bahan ajar tematik pendamping guru ini dengan tingkat perkembangan siswa SD kelas 3. Hasil reviu uji coba perorangan dari beberapa aspek diantaranya tampilan, materi, dan manfaat persentase 90\% dengan kategori baik. Sedangkan berdasarkan hasil uji coba kelompokadalah 5 gurutematikkelas 3 mengisi angket yang diberikan oleh pengembang. Hasil reviu uji kelompok 5 orang responden dari aspek tampilan, aspek penyajian materi dan aspek manfaat mendapatkan persentase 93\% dengan kategori baik.

\section{Hasil Uji Coba Lapangan}

Dalam tahapan ini yaitu uji kelayakan sebagai subyek di lapangan adalah siswa kelas 3B dilakukan di SD Al Falah Assalam dengan responden 24 orang siswa. 24 siswa responden mengisi angket yang diberikan oleh pengembang. Fokus utama ingin diperoleh dari pengembang adalah data kesesuain isi/ materi dan kesesuaian desain pembelajaran produk bahan ajar tematik pendamping guru ini dengan tingkat perkembangan siswa SD kelas 3. Hasil reviu uji coba dari aspek tampilan, aspek penyajian materi dan aspek manfaat mendapatkan persentase $83 \%$ dengan kategori baik.

\section{Pembahasan}

Berdasarkan hasil analisis data secara keseluruhan oleh (1) ahli materi mendapatkan persentase $97 \%$ jika di konversi ke tingkat pencapaian dengan kualifikasi produk pengembangan ditafsirkan dalam kategori baik. (2) Ahli media dengan persentase $83 \%$ sesuai konversi tingkat pencapaian kualifikasi in ditafsirkan dalam kategori baik. (3) Ahli desain dengan persentase $88 \%$ dengan kriteria baik . (4) Guru tematik dan uji kelompok 
dengan skor persentase masing - masing $90 \%$ dan 93 \% sesuai konversi tingkat pencapaian kualifikasi produk ditafsirkan dalam kategori baik. (5) peserta didik memberi penilaian $83 \%$ sesuai konversi tingkat pencapaian kualifikasi produk ditafsirkan dalam kategori baik. Berdasarkan penilaian secara keseluruhan rata rata dari

$$
\frac{97+83+88+88+90+93+83}{7}
$$

Adalah 55,0 dengan persentase $89 \%$. Perubahan signifikan dalam media pembelajaran berdampak sangat baik terhadap minat belajar anak (Hung, Chen, \& Huang, 2017). Pernyataan yang ada adalah guru yang memiliki pengalaman akan segera menyesuaikan dengan teknologi. Sedangkan pengajar yang baru butuh penyesuaian berbeda (Lazar, 2015). Kemampuan guru dalam mengelola kelas merupakan bagian utama dalam pembelajaran (Lai \& Cheung, 2015). Hal ini menunjukkan terdapat hal khusus dalam pengembangan bahan ajar yang menjadi perhatian sebelum diujikan terhadap peserta didik. tentunya dengan referensi yang memadai.

Untuk mendukung pembelajaran yang adaptif guru dituntut mengembangkan bahan ajar yang relevan, dan itu merupakan platform yang terdapat pada program e-learning. Selain itu dengan menggunakan pendekatan prototyping pembuatan bahan ajar menjadi lebih mudah, dimana sebelumnya pembuatan bahan ajar dianggap sulit dan memakan waktu karena masih bersifat tradisional. Pendekatan prototyping berbasis Wiki dengan pembuatan konsep secara otomatis begitu pula dengan revisinya (Shih, Tseng, \& Yang, 2008)and are promising platforms for e-Learning. To support individualized and adaptive learning, teachers are encouraged to develop various teaching materials according to different requirements. However, traditional methodologies for designing teaching materials are timeconsuming. To speed up the development process of teaching materials, our idea is to use a rapid prototyping approach which is based on automatic draft generation and Wiki-based revision. This paper presents the approach named WARP (Wiki-based Authoring by Rapid Prototyping.
Beberapa studi yang telah menunjukan betapa sangat pentingnya peran media dan bahan ajar dalam pembelajaran adalah (Ningsih \& Adesti, 2019; Salim, Suryaman, \& Rusmawati, 2019).

Penelitian bahan ajar dari (Suarman, Hendripides, \& Hikmah, 2018) hasil penilaian ahli dari materi dengan skor rata-rata $89,47 \%$ (sangat baik) dan hasil tanggapan siswa dengan skor rata-rata $86,45 \%$ (sangat baik), dengan demikian bahan ajar layak digunakan dalam pembelajaran hasil penelitian ini juga menambah bukti empiris bahwa bahan ajar dibutuhkan oleh mahasiswa sebagai pedoman atau panduan dalam kegiatan perkuliahan

\section{SIMPULAN}

Hasil reviu para ahli, teman sejawat, para siswa dan uji coba produk sudah menyatakan produk buku bahan ajar pendamping guru layak dipakai dalam pembelajaran siswa kelas 3 SD. Nilai kelayakan pada umumnya pada tingkat kelayakan dan sangat layak sehingga produk yang dikembangkan tidak banyak mengalami revisi. Bahan ajar ini dapat menolong tercapainya tujuan pembelajaran yang diharapkan. Sehingga disimpulkan bahwa buku ajar pendamping guru dengan berbasis E-learning pada pembelajaran tematik sekolah dasar layak dipakai sebagai bahan ajar pembelajaran tematik.

Produk pengembangan ini adalah buku ajar yang merupakan buku sumber belajar pendamping guru untuk aktivitas di sekolah. Tema yang dipilih dan ditetapkan sesuai dengan karakteristik sekolah berdasarkan analisis kebutuhan yang dilakukan sebelum pengembangan dilaksanakan. Karena itu produk dirancang sesuai ciri khas sekolah tempat pengembangan produk dilakukan.

Pemanfaatan bahan ajar tematik berbasis e-learning pada mata pelajaran tematik kelas 3 sekolah dasar perlu ditunjang dengan fasilitas media elektronik pada produk e-learning. Bahan ajar tematik berbasis e-learning pada materi mata pelajaran tematik kelas 3 sekolah dasar dijadikan rujukan oleh guru untuk mencoba mengembangkan bahan ajar yang sesuai dengan karakteristik siswa. 


\section{REFERENSI}

Agustina, P., Al Muhdhar, M. H. I., \& Amin, M. (2017). Integration Of Life Skills In Environment Material Module To Elevate Learning Achievement. Jurnal Kependidikan: Penelitian Inovasi Pembelajaran, 1(2), 291-305.

Amidi, A., \& Zahid, M. Z. (2017). Membangun Kemampuan Berpikir Kreatif Matematis dengan Model Pembelajaran Berbasis Masalah Berbantuan E-Learning. PRISMA, Prosiding Seminar Nasional Matematika, 586-594.

Anshory, I., Saputra, S. Y., \& Amelia, D. J. (2018). Pembelajaran Tematik Integratif pada Kurikulum 2013 di Kelas Rendah SD Muhammadiyah 07 Wajak. JINoP (Jurnal Inovasi Pembelajaran), 4(1), 35-46.

Arham, U. U., \& Dwiningsih, K. (2016). Keefektifan Multimedia Interaktif Berbasis Blended Learning untuk Meningkatkan Hasil Belajar Siswa. Kwangsan, 4(2), 111-118.

Arikunto, S. (2014). Prosedur Penelitian: Suatu Pendekatan Praktik. Jakarta: Rineka Cipta.

Arsah, P. M. (2019). Teacher's Knowledge of Higher Order Thinking Skill in TeachingLearning Process in Senior High School. RETAIN, 7(1), 107-114.

Gall, M. D., Gall, J. P., \& Borg, W. R. (2003). Educational Research: An Introduction (7th Edition). New Jersey: Pearson Education Inc.

Kimianti, F., \& Prasetyo, Z. K. (2019). Pengembangan E-modul IPA Berbasis Problem Based Learning untuk Meningkatkan Literasi Sains Siswa. Kwangsan, 7(2), 91-103.

Lai, E., \& Cheung, D. (2015). Enacting teacher leadership: The role of teachers in bringing about change. Educational Management Administration \& Leadership, 43(5), 673-692.

Lazar, S. (2015). The importance of educational technology in teaching. International Journal of Cognitive Research in Science, Engineering and Education, 3(1).

Mardliyah, A. A. (2019). Budaya Literasi Sebagai Upaya Peningkatan
Keterampilan Berpikir Kritis di Era Industri Revolusi 4.0. Prosiding SNP2M (Seminar Nasional Penelitian Dan Pengabdian Masyarakat) UNIM, 171$176 \%$ N 1.

Mursanti, A. E., Fatirul, A. N., \& Hartono, H. (2020). Pengembangan Bahan Ajar Dasar Tata Rias Wajah untuk Mahasiswa Prodi Pendidikan Vokasional Kesejahteraan Keluarga (PVKK) Tata Rias. Edcomtech Jurnal Kajian Teknologi Pendidikan, 5(1), 76-87.

Ningsih, S., \& Adesti, A. (2019). Pengembangan Mobile Learning Berbasis Android pada Mata Kuliah Strategi Pembelajaran Universitas Baturaja. Edcomtech Jurnal Kajian Teknologi Pendidikan, 4(2), 163172.

Prastowo, A. (2011). Panduan kreatifmembuat bahan ajar inovatif. Yogyakarta: DIVA press.

Pratiwi, P. H., Hidayah, N., \& Martiana, A. (2017). Pengembangan modul mata kuliah penilaian pembelajaran sosiologi berorientasi HOTS. Cakrawala Pendidikan, (2), 85339.

RW, R. S., Mayasari, T., \& Huriawati, F. (2017). Implementasi Media Pembelajaran E-Learning Berbasis Web Materi Elastisitas dan Hukum Hooke untuk Meningkatkan Prestasi Belajar Siswa SMK Negeri 1 Sambirejo. Prosiding SNFA (Seminar Nasional Fisika Dan Aplikasinya), 2, 182-191.

Safitri, A. D. (2018). Enhancing senior high school students' creative thinking skills using project based e-learning. Journal of Physics Conference Series, 1097(1), 012030.

Salim, S., Suryaman, S., \& Rusmawati, R. D. (2019). Keefektifan Tingkatan Pembelajaran Inkuiri (Level Of Inquiry) Terhadap Peningkatan Keterampilan Proses Sains Pada Pengetahuan Awal Siswa Yang Berbeda. Edcomtech Jurnal Kajian Teknologi Pendidikan, 4(2), 96108.

Shih, W.-C., Tseng, S.-S., \& Yang, C.-T. (2008). Wiki-based rapid prototyping for teaching-material design in e-Learning grids. Computers \& Education, 
51(3), 1037-1057. doi: 10.1016/j. compedu.2007.10.007

Surahman, E., Sulthoni, S., Ulfa, S., Husna, A., Ramdiana, H., Thaariq, Z. Z. A., ... Qolbi, M. S. (2020). Pelatihan Micro Learning Object Berbasis TPACK bagi Guru-Guru SMA di Garut. Abdimas Pedagogi: Jurnal Ilmiah Pengabdian Kepada Masyarakat, 3(1), 1-14.

Suryosubroto, B. (2009). Proses Belajar Mengajar di Sekolah. Jakarta: PT Rineka Cipta.

Susilo, A., \& Suhardi, D. A. (2018). Kajian Pemanfaatan Fitur Dan Fasilitas Moodle Dan Office-365 Untuk Peningkatan Kualitas Pembelajaran Pada Tutorial Online. Edcomtech Jurnal Kajian Teknologi Pendidikan, 3(2), 10.

Suyantiningsih, Munawaroh, I., \& Rahmadona, S. (2016). Pengembangan Multimedia Pembelajaran Berbasis Scientific Approach Terintegrasi Nilai Karakter Untuk Siswa Sekolah Dasar Di Yogyakarta. Jurnal Kependidikan: Penelitian Inovasi Pembelajaran, 46(1), 1-13. doi: 10.21831/jk.v46i1.9571

Tay, F., \& Destya, S. (2017). Analisis Fitur E-Learning pada Kurikulum 2013 Dengan Pendekatan Framework Content-Understanding-Environment. Seminar Nasional Informatika (SNIf), 1(1), 442-447.
Thaariq, Z. Z. A. (2020). The Use of Social Media as Learning Resources to Support the New Normal. Teknodika, 18(2), 8093.

Tim Penyusun. (2013). Peraturan Menteri Pendidikan dan Kebudayaan Republik Indonesia Nomor 81A Tahun 2013 Tentang Implementasi Kurikulum. Jakarta: Kemdikbud.

Trianto. (2010). Model Pembelajaran Terpadu Konsep, Strategi, dan Implementasinya dalam Kurikulum Tingkat Satuan Pendidikan (KTSP). Jakarta: Bumi Aksara.

Wahyuni, E. (2018). Pengembangan Bahan ajar Tematik Pendamping Guru Dengan Model Webbed Untuk Sekolah Dasar Kelas 2. Edcomtech Jurnal Kajian Teknologi Pendidikan, 3(2), 8.

Yektyastuti, R., \& Ikhsan, J. (2016). Pengembangan media pembelajaran berbasis android pada materi kelarutan untuk meningkatkan performa akademik siswa SMA.

Zare, M., Pahl, C., Rahnama, H., Nilashi, M., Mardani, A., Ibrahim, O., \& Ahmadi, H. (2016). Multi-criteria decision making approach in E-learning: A systematic review and classification. Applied Soft Computing, 45, 108-128. doi: 10.1016/j. asoc.2016.04.020 